\title{
Erratum to: Purification of Cyclic GMP-AMP from Viruses and Measurement of Its Activity in Cell Culture
}

Alice Mayer, Jonathan Maelfait, Anne Bridgeman, and Jan Rehwinkel

Erratum to:

Chapter 8 in: Karen Mossman (ed.), Innate Antivival Immunity: Methods and Protocols, Methods in Molecular Biology, vol. 1656, https://dx.doi.org/10.1007/978-1-4939-7237-1_8

Chapter 8, 'Purification of Cyclic GMP-AMP from Viruses and Measurement of Its Activity in Cell Culture' is re-published as Open Access under a CC BY 4.0 license, and the copyright holder has been updated as The Author(s) 